\title{
Factors Influencing Performance of Business Process Reengineering Projects in Banks in Kenya: Case of Kenya Commercial Bank
}

\author{
Hezron M. Osano, David M. Okwena \\ Africa Nazarene University, Nairobi, Kenya
}

\begin{abstract}
The Kenyan banking sector has found it is important to take up business process reengineering (BPR) in an attempt to greatly improve performance. The aim of the study was to investigate factors that influence performance of BPR projects in the Kenya Commercial Bank (KCB). The study adopted a descriptive and inferential research design. The target population was 4,066 employees of KCB Ltd from which a sample size of 351 was derived to participate in the study. The study found that management commitment, communication of change, processes and systems management and, monitoring and evaluation influence the performance of BPR projects at KCB Ltd. The study concluded that employees at KCB Ltd were communicated early enough on the business processes; the needs for change were clearly communicated to them. The study concludes that monitoring and evaluation affect BPR through the kind of support offered and participation in strategy formulation. The study recommends that effective change management is a success factor for BPR; organizations should therefore ensure that communication of change is made to enhance the meeting of project objectives and effectively prepare their organizations for change.

Keywords: business process reengineering (BPR), management commitment, communication of change, processes and systems management, monitoring and evaluation
\end{abstract}

Many organizations that have implemented the business process reengineering (BPR) have encountered many challenges during implementation especially resistance and reluctance to change. BPR projects have a failure rate of $70 \%$ due to weak implementation (Hammer \& Champy, 2009). Champy (2010) found that substantial reengineering payoffs appear to have fallen well short of the potential goals of the Business Reengineering Projects. According to Bittock (2012), head of the KCB (Kenya Commercial Bank) BPR team, there are no clear parameters set to finally describe a BPR project as a success. There are a number of factors that influence BPR projects success. They include: management commitment, communication of change, processes and systems management and monitoring and evaluation. Thus, the study investigates the factors that influence performance of BPR projects.

Corresponding author: Hezron M. Osano, Ph.D., senior lecturer, Business School, Africa Nazarene University; research fields: innovation and entrepreneurship, internationalization of SMEs (small and medium-size enterprises), SME finance, science and technology parks, innovation and incubation centres, technology transfer, public-private partnership, industry-university collaborations. E-mail: hezron.osano@gmail.com.

David M. Okwena, MBA, Africa Nazarene University; research fields: business process reengineering and project management. E-mail: dokwena@kcb.co.ke. 


\section{Literature Review}

\section{BPR}

Davenport and Short (1990) gave the definition of a business process as correlated tasks logically arranged and performed to achieve a certain outcome. A process is a set of measured, structured activities designed to produce a specific output for a specific sort of market or customers. BPR projects seek to help businesses to restructure radically their organizations by focusing on the design of their business processes from the bottom to the top.

It is argued that BPR is one of the major business strategies that play a big role in making businesses improve efficiency and be more modern. BPR brings organizational transformation in a way that directly affects performance, efficiency, and cost. According to Davenport and Short (1990), this can be achieved in a five-step process by coming up first with the business vision and process objectives. BPR projects are driven by a business vision which can be broken down into specific business objectives like reduction of costs, improve turnaround time and output quality improvement. Then, one should identify what process to redesign. Most organizations prefer the high-impact approach that gives focus on the most important processes meaning those that mostly not in line with the business vision. BPR is not just simply automation of processes or speeding up using computers, speeding up those processes cannot address their fundamental performance deficiencies. Many of our job designs, work flows, control mechanisms, and organizational structures came of age in a different competitive environment and before the advent of the computer. They are geared toward efficiency and control. Yet, the watchwords of the new decade are innovation and speed, service and quality (Hammer \& Champy, 2009). Regardless of Hammer and Champy's (2009) exhortation stating, do not automate, obliterate, a clean slate change is difficult to find in practice or, as Davenport (1994) stated that a blank sheet of paper used in redesign requires a blank cheque in order to implement. According to Hammer and Champy (2009), there are three kinds of businesses that undertake reengineering: those that find themselves in deep trouble, those that are not in trouble but whose management can see trouble coming, and those that are in peak condition and see an opportunity to develop a lead over their competitors.

\section{Customer Focus}

Customer demands drive most BPR initiatives and more so in the service industry (Hammer \& Champy, 2009). The customer focused approach has also been moved further to include the internal customer such as in the 2000 implementation of Six Sigma at Ford. There have been attempts by recent approaches to redress the balance and have argued that customer support should be a key ingredient in process redesign ventures as opposed to the current methodologies that maintain focus on workflows and little regard for the customer (Walden, 2009). The importance of innovation is known to most of the more enlightened firms, it is not all about process efficiency but also customer experiences and customer expectations. Starwood Hotels for instance, talks about the need to execute across business silos rather than innovation and efficiency within specific processes. Citibank's CEO (chief executive officer) noted that as improvements increase, expectations also increase and therefore customer perceptions will change subsequently driving you to places you never knew existed (Walden, 2009), this is the more reason to embrace a systematic business process improvement with the customer in focus.

\section{BPR in the Banking Sector}

In Nigeria, changes in the financial market, customer demands and increasing competition forced banks to 
re-engineer their business organizations. Nigerian banks had to come up with innovative ways through BPR in order to increase and retain their customer base and improve on service delivery.

An impact assessment on reengineering by Sidikat (2008) indicated that BPR has become a useful weapon for any corporate organization that is seeking to achieve cost leadership strategy in its operating industry and environment and intends to improve in their current organizational performance. For organizations striving to operate effectively and efficiently, it is recommended that BPR remains an effective tool. The BPR has also been found useful in the effecting of innovative and strategic changes (Sidikat, 2008).

In a study done on the perceptions of KCB employees regarding business processes implemented in the bank, it was found that nearly $90 \%$ of employees indicated that they had witnessed major changes in the bank's processes. Most of the respondents agreed that the BPR was necessary for the bank to be competitive and felt that the changes were necessary. The management of the bank had communicated to employees the need for implementing the business processes. It was noted that in the beginning of the implementation, employees were scared that the business processes would impact on them negatively fearing loss of jobs and reduction of responsibility. The perceptions of employees were that the business processes were necessary due to changes in technology, increased competition, and increasing customer demands. The challenges faced were resistance of employees, lack of supporting tools and resources, lack of ownership, inadequate training, and cross functional differences (Tikani, 2012).

\section{Management Commitment and BPR}

According to Hammer and Champy (2009), BPR is the radical rethinking of existing organizational functions and operational flows with the aim of achieving dramatic improvement. Commitment and leadership and more so from top management are often cited as the main factors that influence the success of BPR projects (Hall, Rosenthal, \& Wade, 1993). BPR efforts will be normally implemented in the most effective manner through sound management and leadership (Bashein, Markus, \& Riley, 1994). Top management commitment, support, championship, sponsorship, and effective management of risks are the most noticeable managerial practices that seem to directly influence the success of BPR execution (Zairi \& Al-Mashari, 1999).

In an organization implementing change, it is a prerequisite that the leaders be visionaries, motivators, communicators, and leg breakers. Leadership has to be fully committed to the change but middle managements' view of the change and unwillingness to change is one issue that remains a problem (Elmuti \& Kathawala, 2011). Paper and Chang (2005) therefore suggested that top-down imperatives should be tempered with involvement from people along the process path.

\section{Change Communication and BPR}

BPR has often been associated with downsizing which is incorrect (Hammer \& Champy, 2009). Nobody likes to lose their job and would resist the implementation of any new changes if they understood BPR to be cutting down of staff. Communication of change is one useful tool for managing the human, political, and social aspects which entail the soft issues. It can be argued that BPR invariably has resulted in massive changes to organizations.

The main concern of employees is the effect of the BPR efforts on their job security and this will often be manifested through a growing opposition to the project. Employers must find a way of confronting this by dealing with the concerns of employees and not engaging in their arguments (Cartland, 1998).

BPR entails radical change and therefore the need for managing change in BPR implementation cannot be overemphasized. It is argued that effective change management ranks second only to management commitment 
in terms of criticality as a success factor for BPR, therefore a significant number of BPR projects are bound to fail in meeting project objectives simply due to failure to effectively prepare the organization for change (McQueen \& Baker, 1996).

\section{Processes and Systems Management and BPR}

Effective process and systems management is equally important and should embrace best practice. This should begin with process redesign which entails the documentation of existing processes, selection of core processes, identification of gaps, and evaluation of effectiveness of current processes. It also involves adequate identification of process gaps and evaluation of effectiveness of current processes by making use of appropriate software tools to visualise and analyse them (Tower, 1994). Identifying process owners is also important to project implementation. In addition, the redesign of processes must have a direct impact on customer value and cost.

BPR projects are an aspect that promotes change and introduces new processes and new styles of workings, so certain elements will be required to make change possible. Among these elements is information technology (IT) management that cannot be ignored during radical redesign of modern organizations. IT promotes changes in organizations, mainly changes in the nature of the work, the integration of business functions, and the transformation of competitive forces (Scott-Morton, 1991). There are two dimensions of classifying processes independently; these are by degree of mediation and by degree of collaboration. The sequential flow of input and output among the participants' functions within a business process is referred to as the degree of mediation. A process at a high degree of mediation involves a large number of intermediate steps, performed in various functions that contribute indirectly to the process outcome while a process at a low degree of mediation has several functions that contribute directly to the process outcome without the mediation of sequential steps (Teng, Grover, \& Fiedler, 1994). The frequency and intensity of information exchange can range from none, process at the low degree of collaboration, to extensive which is process at the high degree of collaboration. Companies may not be able to do this if they use processes with many steps and scarce collaboration, so this environment forces a change in business processes to feature reduced mediation and increased collaboration (Teng et al., 1994).

Tsai (2003) defined IT capabilities as the extent to which an organization is equipped with IT infrastructure, IT skills knowledge and experience as well as effective IT operations utilization. A high level of IT experience enables the smooth implementation of the BPR projects especially when new information systems are acquired. This knowledge assists in developing reliable and cost effective systems for the organization that anticipates customer needs (Bhatt \& Grover, 2005). Brancheau, Janz, and Wetherbe (1996) indicated that IT infrastructure related factors have many researchers and practitioners increasingly considering them a vital component of successful BPR efforts.

Competency in IT function and effective use of software tools have been proposed as some of the most important factors that contribute to the success of BPR projects. They include: building of effective IT infrastructure, adequate investment in IT infrastructure, adequate measurement of effectiveness of the infrastructure, and proper integration of the infrastructure to the existing business processes and systems. Kettinger, Teng, and Guha (1997) went on to state that IT infrastructure strategies and BPR strategies which should both be derived from organizational strategy, need to be in effective alignment to ensure the success of the BPR projects. 
The BPR projects performance improvement goals and key performance indicators should be clear to all staff (Hammer, 1990). Implementation of BPR is highly dependent on an effective project management as existing processes would be redesigned and new process would be created by abolishing the existing organizational functions (Davenport \& Short, 1990). The importance of effective project management cannot be overlooked in the proper planning and management of BPR implementation (Zairi \& Al-Mashari, 1999).

\section{Monitoring and Evaluation and BPR}

All high performing organizations, whether private or public have an interest in developing and deploying effective systems for measurement and management of performance. It is contended that there are different measures deployed to monitor performance, one is outcome which is an assessment of the results of a program compared with its intended purpose, output, impact and another is input measures used to monitor performance of organizations and employees (Hagel, 1993).

There are customer-related measures which consist of complaints, customer satisfaction levels, timeliness or response time, adherence to schedule and responsiveness that are also some of the parameters that can be used to measure services delivered to customers. For effective performance measurement, you need to include a mix of outcome, output, and efficiency measures and these should be linked with the business strategic goals and should be integrated into organization wide performance measurement system (Zairi \& Al-Mashari, 1999).

\section{BPR Successes and Failures}

It is estimated that approximately 70\% of BPR projects failed and authors have found evidence that displays reengineering projects consistently falling short of the dramatic or expected benefits (Currie \& Willcocks, 1996). For instance, in a study carried out on one hundred (100) companies to assess the success of their BPR projects, of all of them, only 18 firms reported completed projects that resulted in reducing the costs of doing business by over $10 \%$ and increase in profits by over $20 \%$ (Anderson, 1993). According to Anderson (1993), among the companies that topped the list in implementing change in the way they conducted business were influenced mostly by information technology (84.2\%), BPR (80.3\%), and business strategy development.

The most harsh and frequent critique against BPR is the strict focus on efficiency and technology with disregard of the human factor in the organizations subjected to a reengineering initiative. Davenport and Short (1990) explicitly stated that using BPR for cost reduction alone was not a sensible goal as very often BPR was used as a label for major workforce reductions. Research studies have shown $60 \%-70 \%$ of BPR efforts have either failed or did not achieve the expected benefits (Hammer \& Champy, 2009). BPR improves firm performance. A study analyzing performance measures in selected companies in the US using human resource productivity, return on assets and return on equity showed that performance of the firms increased after the BPR projects are finalized, while it remained unaffected during execution. It was also found that functionally focused BPR projects contribute more to performance than those with a broader cross-functional scope on average (Ozcelik, 2010).

According to Boudreau and Robey (1995), it is important to directly examine and scrutinize contradictions in order to assess the value of BPR. The thorough analysis of contradictions led Boudreau and Robey (1995) to propose alternative theoretical approaches to BPR research and practice. These theories employed a logic of contradiction are likely to offer greater insight into contradictory practices such as BPR, as well as the more 
general issue of organizational change (D. Ford \& L. Ford, 1994; Boudreau \& Robey, 1995). Rather than criticizing BPR, it is better to understand the logical inconsistencies in the process. They argued that empirical research on BPR has implications for organizational performance and, ultimately, applied reengineering efforts can both be improved by a better understanding of theory (D. Ford \& L. Ford, 1994; Boudreau \& Robey, 1995).

Two major problems of BPR are the definition of BPR and how to monitor whether it has been successfully applied. BPR has often been associated with downsizing which is incorrect (Hammer \& Champy, 2009). Nobody likes to lose their job and would resist the implementation of new processes if they understood BPR to be cutting down of staff. The research examined four contradictions of BPR mainly analysis of organizations, the fallacy of BPR of assuming a clean slate start, the paradox of information technology's role as more than organizational change enabler, the irony of employee commitment and the hypocrisy of employee empowerment. Research shows that there is a need for a better understanding BPR in today's business environment (Tsai, 2003).

There is a need for better research and better practice due to the amount of effort and resources invested in BPR. It is time for researchers interested in BPR to accept the fact that BPR is a complex phenomenon with aspects both technical and social as opposed to just a quick fix for huge performance improvements. The BPR human resource implications need to be dealt with more realistically. It is difficult to state that BPR leads to job empowerment when jobs are eliminated when the process is implemented. People will not sensibly commit time and effort into major programmes of change that eliminate their own roles in organizational success. They will therefore resist any change and therefore change management then becomes an issue in the success of the BPR process (Tesfaye, 2009).

\section{Conceptual Framework}

The independent variables for the study are management commitment, communication of change, processes and systems management, and monitoring and evaluation. Management commitment was measured by assessing the management input in terms of knowledge, motivation, and sponsorship and its influence on the project success. Communication of change was measured through effective communication prior and during the study, adequate education and training on required skill, executive support, organizational planning and analysis. Processes and systems management was assessed by analyzing how the new process is arrived at, the incorporation of information technology and whether the methodologies agree with best practice. Customer focus was measured by assessment of customer considerations that drive BPR in the bank and whether the customer centric changes have translated to customer satisfaction.

Figure 1 shows the independent variables management commitment, communication of change, processes and systems management, and monitoring and evaluation and how they relate to the dependent variable the performance of BPR projects.

\section{Research Methodology}

A descriptive and inferential survey was undertaken. The target population of this study is the Kenyan banking industry. The employees included all levels from management to non-management who were 4,066 in number and a sample size of 351 was arrived using Krejcie and Morgan (1970) formula. Primary data were collected from the employees with the aid of structured questionnaires. 


\section{Conceptual framework}

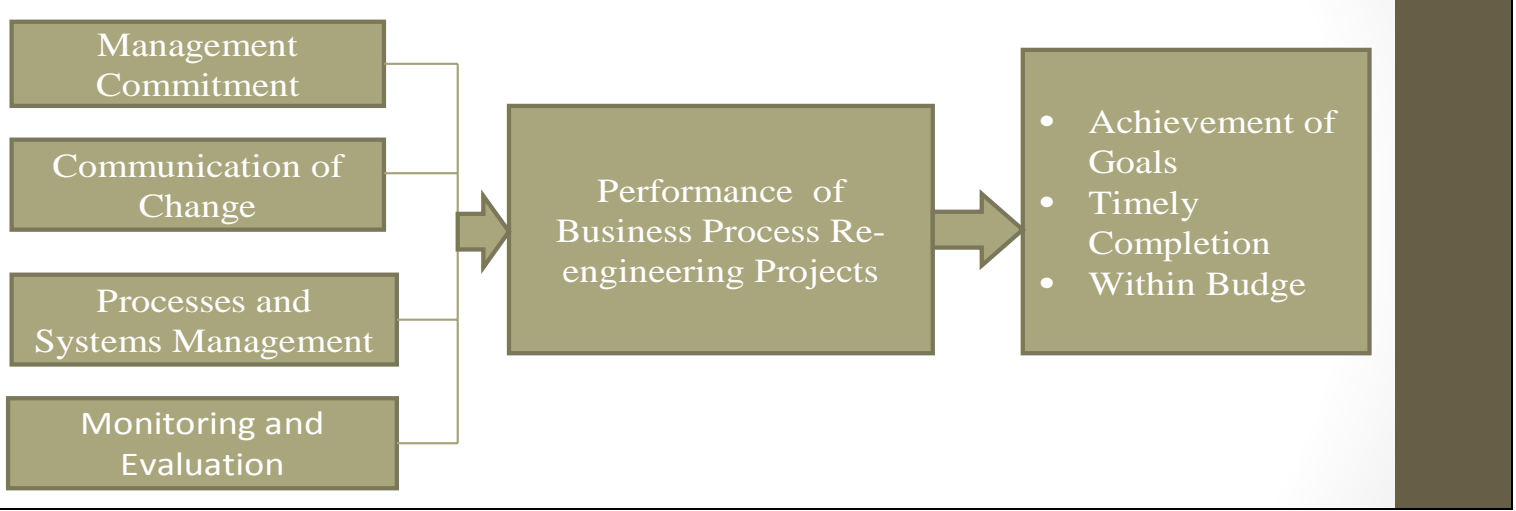

Figure 1. Conceptual framework.

The results were presented on the factors that influence performance of BPR projects in the KCB. The study targeted a total of 351 respondents out of which 269 responded and returned their questionnaires contributing to $76.64 \%$ response rate.

\section{Discussion of Findings and Recommendations}

\section{Reliability Results}

Reliability was calculated with the help of SPSS. A Cronbach's alpha correlation coefficient greater or equal to 0.6 was accepted (George \& Mallery, 2003).

The analysis involved questionnaires from seven respondents and the alpha coefficients were all greater than 0.7 indicating an acceptable reliability of the instruments. The instrument therefore was appropriate for the study (see Table 1).

Table 1

Reliability Results

\begin{tabular}{lll}
\hline Variable & Cronbach’s alpha & No. of items \\
\hline Management commitment & 0.7069 & 5 \\
Communication of change & 0.8390 & 6 \\
Processes and systems management & 0.7110 & 3 \\
Monitoring and evaluation & 0.8298 & 4 \\
\hline
\end{tabular}

\section{Pearson's Correlation Matrix}

The study conducted a correlation analysis of the specific objectives of the study management commitment, communication of change, monitoring and evaluation, and processes and systems management. To quantify the strength of the relationship between the variables, the study used Karl Pearson's coefficient of correlation.

From the findings (see Table 2), show that there is a positive correlation between management commitment and communication of change as shown by a correlation figure of 0.331 , and a positive correlation between performance of BPR projects and monitoring and evaluation with a correlation figure of 0.564 significant 0.001 (2-tailed). 
Table 2

Pearson Correlation Coefficient Matrix

\begin{tabular}{llllll}
\hline & $\begin{array}{l}\text { Management } \\
\text { commitment }\end{array}$ & $\begin{array}{l}\text { Communication } \\
\text { of change }\end{array}$ & $\begin{array}{l}\text { Processes and } \\
\text { systems } \\
\text { management }\end{array}$ & $\begin{array}{l}\text { Monitoring and } \\
\text { evaluation }\end{array}$ & $\begin{array}{l}\text { Performance of } \\
\text { BPR projects }\end{array}$ \\
\hline Management commitment & 1 & 0.331 & 0.054 & $0.564\left(^{* *}\right)$ & 0.087 \\
Sig. (2-tailed) & 0.0 & 0.056 & 0.010 & 0.001 & 0.025 \\
Communication of change & 0.331 & 1 & 0.062 & 0.141 & 0.294 \\
Sig. (2-tailed) & 0.056 & 0.0 & 0.726 & 0.425 & 0.091 \\
Processes and systems management & 0.054 & -0.062 & 1 & 0.065 & 0.055 \\
Sig. (2-tailed) & 0.760 & 0.726 & 0.0 & 0.716 & 0.756 \\
Monitoring and Evaluation & $0.564\left(^{* *}\right)$ & 0.141 & 0.065 & 1 & 0.309 \\
Sig. (2-tailed) & 0.001 & 0.425 & 0.716 & 0.0 & 0.076 \\
Performance of BPR projects & 0.087 & 0.294 & 0.055 & 0.309 & 1 \\
Sig. (2-tailed) & 0.625 & 0.091 & 0.756 & 0.076 & 0.0 \\
\hline
\end{tabular}

Note. ${ }^{* *}$ Correlation is significant at the 0.01 level (2-tailed).

The researcher used the Karl Pearson's coefficient of correlation $(\mathrm{R})$ to study the correlation between the study variables and the findings. From the findings, it was clear that there was a positive correlation between management commitment and communication of change as shown by a correlation figure of 0.331 , it was also clear that there was a positive correlation between performance of BPR projects and monitoring and evaluation with a correlation figure of 0.309 . This shows that there was positive correlation among performance of BPR projects and management commitment, communication of change, monitoring and evaluation, and processes and systems management.

\section{Regression Analysis}

A multiple linear regressions of variables were carried out. Table 3 is a summary of model and indicates the Adjusted R squared used as test for model fitness. The F-test was carried out to test the significance of the regression model in predicting the dependent variable (performance of BPR). From the results, it is clear that the four independent variables moderately predict the performance of BPR at KCB Ltd (adjusted R squared = 0.703). That means the model explains $70.3 \%$ the variance in the performance of $B P R, 29.7 \%$ of variations are brought about by factors not captured in the objectives.

Table 3

\section{Coefficient of Determination $\left(R^{2}\right)$}

\begin{tabular}{lllll}
\hline Model & $\mathrm{R}$ & $\mathrm{R}$ Square & Adjusted R square & Std. error of the estimate \\
\hline 1 & $0.853(\mathrm{a})$ & 0.727 & 0.703 & 0.71600 \\
\hline
\end{tabular}

Note. a Predictors: (Constant), management commitment, communication of change, monitoring and evaluation, and processes and systems management.

Table 4 indicates the F-test results for the regression model. The null hypothesis was rejected because the linear regression F-test results, ( $F=4.398$, and $29 \mathrm{df})$ compared to the critical values of F-test $(4,29$ at 0.05 alpha is 1.2225), indicates that the critical $\mathrm{F}$ value is less than the computed F-value. Therefore, the null hypothesis was rejected and concluded that, the regression model linearly explains the performance of BPR. Therefore, the study accepted $\mathrm{H}_{1}, \mathrm{H}_{2}, \mathrm{H}_{3}$, and $\mathrm{H}_{4}$.

Table 5 presents the regression coefficient of determination for the variables between management commitment, 
communication of change, monitoring and evaluation, and processes and systems management and performance of BPR. Of all the four independent variables, management commitment had the highest relationship with the performance of BPR $\left(R^{2}=0.004\right)$ followed by process and system management $\left(R^{2}=0.119\right)$. Monitoring and evaluation was third $\left(R^{2}=0.098\right)$ and lastly, communication of change was fourth $\left(R^{2}=0.035\right)$.

The study conducted a multiple regression analysis so as to determine the relationship between the (management commitment, communication of change, monitoring and evaluation, and processes and systems management) and performance of BPR.

The standardized coefficients assess the contribution of each independent variable toward the prediction of the dependent variable, since they have been converted in the same scale to show comparison.

The result indicates that management commitment having the highest beta of 0.586 has the largest influence on performance of BPR. The second most important variable was processes and systems management with a beta of 0.609. The third most important variable was monitoring and evaluation with a beta of 0.387 . The least important predictor of these five variables is communication of change with a beta of 0.238 . The t-test statistic shows that all the B coefficients of management commitment, communication of change, monitoring and evaluation, and processes and systems management are significant (since $p<0.05$ ) (see Table 6).

Table 4

ANOVA ${ }^{b}$

\begin{tabular}{lllllll}
\hline Model & & Sum of squares & df & Mean square & F & Sig. \\
\hline 1 & Regression & 6.227 & 14 & 1.557 & 4.398 & $0.034(\mathrm{a})$ \\
& Residual & 18.831 & 254 & 0.649 & & \\
& Total & 25.059 & 268 & & & \\
\hline
\end{tabular}

Notes. a Predictors: (Constant), management commitment, communication of change, monitoring and evaluation, and processes and systems management; ${ }^{\mathrm{b}}$ Dependent Variable: performance of BPR.

Table 5

Regression Analysis Results-Coefficient of Determination $\left(R^{2}\right)^{b}$

\begin{tabular}{lllll}
\hline Model & $\mathrm{R}$ & $\mathrm{R}$ square & Adjusted R square & Std. error of the estimate \\
\hline Management commitment & $0.484(\mathrm{a})$ & 0.234 & 0.004 & 0.98331 \\
Process and system management & $0.382(\mathrm{a})$ & 0.146 & 0.119 & 0.92445 \\
Monitoring and evaluation & $0.355(\mathrm{a})$ & 0.126 & 0.098 & 0.93544 \\
communication of change & $0.253(\mathrm{a})$ & 0.064 & 0.035 & 0.96779
\end{tabular}

Notes. a Predictors: (Constant), management commitment, communication of change, monitoring and evaluation, processes and system management; ${ }^{\mathrm{b}}$ Dependent Variable: performance of BPR.

Table 6

Regression Analysis Results-Regression Coefficients ${ }^{b}$

\begin{tabular}{llllll}
\hline & \multicolumn{2}{c}{ Unstandardized coefficients } & \multicolumn{2}{c}{$\begin{array}{l}\text { Standardized } \\
\text { coefficients }\end{array}$} & Sig. \\
\cline { 2 - 5 } & $\mathrm{B}$ & Std. error & Beta & & \\
\hline (Constant) & 1.147 & 0.393 & & 0.915 & 0.000 \\
Management commitment (a) & 0.488 & 0.256 & 0.586 & 1.908 & 0.001 \\
Communication of change (a) & 0.166 & 0.191 & 0.238 & 0.868 & 0.033 \\
Processes and systems management (a) & 0.434 & 0.195 & 0.609 & 2.221 & 0.031 \\
Monitoring and evaluation (a) & 0.269 & 0.135 & 0.387 & 1.991 & 0.003 \\
\hline
\end{tabular}

Notes. a Predictors: (Constant), management commitment, communication of change, monitoring and evaluation, processes and system management; ${ }^{b}$ Dependent Variable: performance of BPR. 


\section{The Influence of Management Commitment on Performance of BPR Projects}

The study found that management commitment affects the performance of BPR projects to a great extent. According to Hall et al. (1993), commitment and leadership and more so from top management are the main factors that influence the success of BPR projects. This finding implies that BPR efforts will be normally implemented in the most effective manner if there is sound management and leadership.

\section{The Influence of Communication of Change on the Performance of BPR Projects}

The study showed that employees at KCB Ltd were communicated early enough on the business processes, the needs for change were clearly communicated to them and that they found the communication of the change very effective in ensuring smooth implementation of BPR. The study therefore infers that change if not introduced in a planned and systematic way will often be associated with uncertainty and is usually resisted by employees and even some of management.

\section{The Influence of Processes and Systems Management on BPR Performance of Projects}

The study showed that process and system management affects the performance of BPR at KCB Ltd. The study also showed that the change projects involved changes in IT systems and employees. According to Tsai (2003), a high level of IT experience enables the smooth implementation of the BPR projects especially when new information systems are acquired. The study therefore concludes that IT infrastructure related factors are a vital component of successful BPR efforts.

\section{The Influence of Monitoring and Evaluation on Performance of BPR Projects}

The study revealed that monitoring and evaluation affect the performance of BPR projects at KCB Ltd to a great extent. Monitoring and evaluation affect BPR through the kind of support offered and participation in strategy formulation. For effective performance measurement, there is a need to include a mix of outcome, output, and efficiency measures and these should be linked with the business strategic goals and should be integrated into organization wide performance measurement system.

\section{Conclusions}

Management commitment affects the performance of BPR project at KCB Ltd to a great extent. They are supportive to ensure successful BPR execution. Employees at KCB Ltd were communicated early enough on the business processes, the needs for change were clearly communicated to them and that they found the communication of the change very effective in ensuring smooth implementation of BPR. Further, the study concludes that process and system management affects the performance of BPR at KCB Ltd. And lastly, the study concludes that monitoring and evaluation affect the performance of BPR projects at KCB Ltd. to a great extent, the respondents felt that monitoring and evaluation affect BPR through the kind of support they offer and participation in strategy formulation.

\section{Recommendations}

BPR efforts should be normally implemented in the most effective manner through sound management and leadership, this is because top management commitment, support, championship, sponsorship, and effective management of risks are the most noticeable managerial practices that seem to directly influence the success of BPR execution. Effective change management is a success factor for BPR, organizations should therefore ensure communication of change is made to enhance the meeting of project objectives and effectively 
prepare their organizations for change.

IT management is vital during radical redesign of modern organizations. IT promotes changes in organizations, mainly changes in the nature of the work, the integration of business functions, and the transformation of competitive forces (Scott-Morton, 1991). Lastly, process and systems management seemed to be most influential in a banking setting. It is core in the success of any BPR project. It is therefore recommended that further study be done to establish the effect of process and systems management in banking in ensuring effective and efficient service delivery.

\section{References}

Anderson, G. (1993). The state of research on information systems success-A review of existing multidimensional approaches. Business \& Information Systems Engineering, 4, 315-325.

Bashein, B. J., Markus, M. L., \& Riley, P. (1994). Preconditions for BPR success: And how to prevent Failure. Information System Management, 11(2), 7-13.

Bhatt, G. D., \& Grover, V. (2005). Types of information technology capabilities and their role in competitive advantage: An empirical study. Journal of Management Information Systems, 22(2), 253-277.

Bittock, E. (2012). Head business process reengineering and project management. D. M. Okwena, Interviewer. June 16.

Boudreau, N., \& Robey, M. (1995). A conceptual framework for understanding business processes and business process modeling. Information Systems Journal, 10, 105-129.

Brancheau, J. C., Janz, B. D., \& Wetherbe, J. C. (1996). Key issues in information systems management: 1994-95 SIM Delphi results. MIS Quarterly, 20(2), 225-242.

Cartland. (1998). Business administration 542. Retrieved from http://www.bus.iastate.edu/hndrcksn/MIS503/sample.doc

Champy, J. (2010). Reengineering health care: A manifesto for radically rethinking health care delivery. London: Harper Collins.

Clark, T. H., \& Stoddard, D. B. (1996). Inter-organizational business process redesign: Merging technological and process innovation. Journal of Management Information Systems, 13(2), 9-28.

Currie, W. L., \& Willcocks, L. (1996). The New Branch Columbus project at Royal Bank of Scotland: The implementation of large scale business process reengineering. Journal of Strategic Information Systems, 5, 213-226.

Davenport, T. H. (1993). Process innovation: Reengineering work through information technology. Boston, Massachusetts: Harvard Business School Press.

Davenport, T. H. (1994). Reengineering: Business change of mythic proportions? MIS Quarterly, 18(2), 121-127.

Davenport, T. H., \& Short, J. E. (1990). The new industrial engineering: Information technology and business process redesign. Sloan Management Review, 31(4), 11-27.

Elmuti, D., \& Kathawala, Y. (2011). An investigation of the human resources management practices of Japanese subsidiaries in the Arabian Gulf region. Journal of Applied Business Research (JABR), 7(2), 82-88.

Ford, D., \& Ford, L. (1994). Logics of identity, contradiction, and attraction in change. Academy of Management Review, 19(4), 756-785.

George, D., \& Mallery, P. (2003). SPSS for Windows step by step: A simple guide and reference. 11.0 update (4th ed.). Boston: Allyn \& Bacon.

Hagel, G. (1993). Assessment of process improvement from organizational change. Information and Management, 45(5), 270-280.

Hall, G., Rosenthal, J., \& Wade, J. (1993). How to make re-engineering really work. Harvard Business Review, 71(6), 119-131.

Hammer, M. (1990). Re-engineering work: Don't automate, obliterate. Harvard Business Review, 68(4), 104-112.

Hammer, M., \& Champy, J. (2009). Reengineering the corporation: A manifesto for business revolution. London: HarperCollins Publishers.

Kettinger, J., Teng, C., \& Guha, S. (1997). Business process change: A study of methodologies, techniques, and tools. MIS Quarterly, 21(1), 55-80.

Krejcie, R. V., \& Morgan, D. W. (1970). Determining sample size for research activities. Educational and Psychological Measurement, 30(3), 607-610.

McQueen, R. J., \& Baker, M. (1996). BPR in the public sector: A case of successful failure. Business Process Management Journal, 1(2), 3-6. 
Ozcelik, Y. (2010). Do business process reengineering projects payoff? Evidence from the United States. International Journal of Project Management, 28(1), 7-13.

Paper, D., \& Chang, R. D. (2005). The state of business process reengineering: A search for success factors. Total Quality Management \& Business Excellence, 16(1), 121-133.

Scott-Morton, M. S. (1991). The corporation of the 1990s: Information technology and organizational transformation. New York, NY: Oxford University Press.

Sidikat, A. (2008). Impact assessment of business process reengineering on organisational performance. European Journal of Social Sciences, 7(1), 115-125.

Teng, J. T. C., Grover, V., \& Fiedler, K. D. (1994). Business process reengineering: Charting a strategic path for the information age. California Management Review, 36(3), 9-31.

Tesfaye, D. (2009). Conceptual framework of business process reengineering for civil service organizations. JBAS, 1 (2), 45-47.

Tikani, P. (2012). Chief operating officer Kenya Commercial Bank. D. M. Okwena, Interviewer. June 13.

Tower, E. (1994). Strategies for business process reengineering: Evidence from field studies. Journal of Management Information Systems, 12(1), 31-56.

Tsai, H. (2003). Information technology and business process reengineering: New perspectives (Vol. 1). New York: Greenwood Publishing Group.

Walden, S. (2009). How BPR and six sigma use the voice of the customer. Retrieved from http://www.beyondphilosophy. com/blog/how-bpr-and-six-sigma-use-voice-customer

Walter, H. (1994). AI in business-process reengineering. AI Magazine, 15(4), 71.

Zairi, M., \& Al-Mashari. (1999). Business process reengineering process: An analysis of key success and failure factors. Business Process Management Journal, 5(1), 87-112. 